(August 8, 2020)

\title{
Tau protein in smooth muscle cells and tissues
}

\author{
Nataliia V. Shults, ${ }^{1}$ Sarah Seeherman, ${ }^{1}$ Nurefsan E. Sariipek, ${ }^{1}$ \\ Vladyslava Rybka, ${ }^{1}$ Lucia Marcocci, ${ }^{2}$ Sergiy G. Gychka, ${ }^{3}$ Yasmine F. Ibrahim, ${ }^{4}$ \\ and Yuichiro J. Suzuki ${ }^{1}$ * \\ ${ }^{1}$ Department of Pharmacology and Physiology, Georgetown University Medical Center, \\ Washington, DC 20007 USA \\ ${ }^{2}$ Department of Biochemical Sciences “A. Rossi Fanelli”, Sapienza University of Rome, \\ Rome, Italy \\ ${ }^{3}$ Department of Pathological Anatomy N2, Bogomolets National Medical University, \\ Kiev, 01601 Ukraine \\ and \\ ${ }^{4}$ Department of Pharmacology, Minia University Faculty of Medicine, \\ Minia, 61111 Egypt
}

*To whom correspondence should be addressed:

Prof. Yuichiro J. Suzuki

Department of Pharmacology and Physiology

Georgetown University Medical Center

3900 Reservoir Road NW

Washington, DC 20007 USA

TEL: (202) 687-8090

FAX: (202) 687-8825

e-mail: ys82@georgetown.edu

Running title: Smooth muscle tau protein 


\begin{abstract}
Tau is a microtubule-associated protein and plays a critical role in the pathophysiology of neurons. However, whether tau protein is expressed in smooth muscle cells is unknown. Here, we report that tau protein is expressed and is constitutively phosphorylated at threonine 181 in various smooth muscle cell types, including human cerebral artery smooth muscle cells, human pulmonary artery smooth muscle cells, and human bronchial airway smooth muscle cells. We also detected the expression of tau protein in the vascular smooth muscle of brain tissues from patients with systemic hypertension who died of ischemic stroke. Immunofluorescence staining revealed that phosphorylated tau at threonine 181 is more organized in the cell than does total tau protein. A protein phosphatase inhibitor, calyculin A induced the formation of higher molecular weight species of phosphorylated tau as visualized by Western blotting, indicating the occurrence of tau aggregation. Immunofluorescence also showed that calyculin A caused the aggregation of phosphorylated tau and disrupted the cytoskeletal organization. These results demonstrate the existence of tau protein in smooth muscle cells and tissues and that smooth muscle tau is susceptible to protein phosphorylation and aggregation.
\end{abstract}

Keywords: Aggregation, Phosphorylation, Protein, Smooth muscle, Tau 


\section{Introduction}

Tau is a microtubule-associated protein and a natively unfolded protein lacking a significant amount of secondary structure (Grundke-Iqbal et al., 1986). Tau promotes the selfassembly of tubulin into the microtubule and plays an important role in microtubule stabilization in the cell (Binder et al., 1985; Qiang et al., 2018). In physiological conditions, tau as a stabilizer of microtubules regulates cell differentiation and proliferation (Evans et al., 2018; Drubin \& Kirschner, 1986; Weingarten et al., 1975). However, under pathological conditions, tau proteins assembly into insoluble aggregates, a hallmark of most neurodegenerative diseases referred to as tauopathies (Saha et al., 2019; Mudher et al., 2017; Mukrash et al., 2017; Narasimhan et al., 2017). The abnormal deposition of misprocessed and aggregated tau proteins in the neuromuscular system contributes to the development of supranuclear palsy, corticobasal degeneration, Pick's disease, Huntington's disease, argyrophilic grain disease, frontotemporal dementia and parkinsonism linked to chromosome 17, and globular glial tauopathy (Vuono, et al., 2015; Fernández-Nogales et al., 2018; Ballatore et al., 2007; Chin \& Goldman, 1996; Feany \& Dickson, 1996; Komori, 1999; Poorkaj et al., 1998). Also, the tau protein aggregation in the brain intracellular fibrils (neurofibrillary tangles) is a major hallmark of Alzheimer's disease, the most common neurodegenerative dementia (Rossi et al., 2013; Rossi et al., 2008; Ittner et al., 2010; Johnson \& Hartigan, 1999; Braak \& Braak, 1991). Phosphorylation of tau contributes to disease-associated tau toxicity (Wang \& Mandelkow, 2016; Šimić et al., 2016; Ittner et al., 2010; Khurana et al., 2006; Steinhilb et al., 2007). Tau is also expressed in non-neural cells including fibroblasts and lymphocytes (Ingelson et al., 1996; Thurston et al., 1996).

In many neurodegenerative disorders, the vascular component has a significant impact on brain metabolism and homeostasis. The loss of vasculature smooth muscle cells in Alzheimer's 
disease impairs the clearance of $\beta$-amyloid and other toxic metabolites (ElAli et al., 2013; Hawkes et al., 2013; Meyer et al., 2008; Ervin et al., 2004).

Since it is not known if tau protein is expressed in smooth muscle cells and tissues, the present study examined the expression of tau protein in the smooth muscle. We found that various types of smooth muscle cells express tau protein that is subjected to protein phosphorylation and aggregation.

\section{Materials and Methods}

\section{Histological measurements of human brain}

Postmortem brain tissues were collected from patients with a history of systemic hypertension and who died of ischemic stroke. The tissues were taken from the perifocal zone of the ischemic infarct in region of the middle cerebral artery of the frontal lobe. Clinical studies were approved by the regional committee for medical research ethics in Kiev, Ukraine (ethical code: 81, 2016) and performed under the Helsinki Declaration of 1975 revised in 2013 or comparable ethical standards.

Brain tissues were immersed in buffered $10 \%$ formalin at room temperature and embedded in paraffin. Paraffin-embedded tissues were cut and mounted on glass slides. Tissue sections were subjected to immunohistochemistry using the Tau antibody (MilliporeSigma, Burlington, MA, USA).

\section{Cell Culture}

Human brain vascular smooth muscle cells, human pulmonary artery smooth muscle cells, and human bronchial smooth muscle cells were purchased from ScienCell Research 
Laboratories (Carlsbad, CA, USA). Cells were cultured in accordance with the manufacturer's instructions in $5 \% \mathrm{CO}_{2}$ at $37^{\circ} \mathrm{C}$. Cells were treated with calyculin $\mathrm{A}$ or $\mathrm{H}_{2} \mathrm{O}_{2}$ purchased from MilliporeSigma. For siRNA experiments, cells were transfected with an siRNA Transfection Reagent and control, Tau (h) or Tau (h2) siRNA from Santa Cruz Biotechnology (Dallas, TX, USA). 48 hours later, cell lysates were prepared.

\section{Western blotting}

To prepare cell lysates, cells were washed in phosphate buffered saline and solubilized with lysis buffer containing $50 \mathrm{mM}$ Hepes (pH 7.4), 1\% (v/v) Triton X-100, 4 mM EDTA, $1 \mathrm{mM}$ sodium fluoride, $0.1 \mathrm{mM}$ sodium orthovanadate, $1 \mathrm{mM}$ tetrasodium pyrophosphate, $2 \mathrm{mM}$ PMSF, $10 \mu \mathrm{g} / \mathrm{ml}$ leupeptin, and $10 \mu \mathrm{g} / \mathrm{ml}$ aprotinin. Samples were then centrifuged at $16,000 \mathrm{~g}$ for 10 min at $4^{\circ} \mathrm{C}$, supernatants collected, and protein concentrations determined.

Equal amounts of protein samples were electrophoresed through a reducing sodium dodecyl sulfate polyacrylamide gel. Proteins in the gel were then electro-transferred to the Immobilon-FL Transfer Membrane (MilliporeSigma, Burlington, MA, USA). The membrane was blocked with Odyssey blocking buffer (LI-COR, Lincoln, NE, USA) for one hour at $25^{\circ} \mathrm{C}$ and incubated overnight with the rabbit anti-tau (C-terminal) antibody (MilliporeSigma) or the mouse anti-phospho-Tau (Thr181) Clone AT270 antibody (Thermo Fisher Scientific, Waltham, MA, USA) at $4^{\circ} \mathrm{C}$. Washed membranes were then incubated with IRDye 680RD or IRDye 800CW (LI-COR) for one hour. Signals were obtained by using the Odyssey Infrared Imaging System (LI-COR). 


\section{Immunofluorescence}

Immunofluorescent analysis of tau protein and phosphorylated tau at threonine 181 was performed on $70 \%$ confluent human pulmonary artery smooth muscle cells. The cells were fixed with $4 \%$ paraformaldehyde for 15 minutes, permeabilized with $0.25 \%$ Triton $\mathrm{X}-100$ for 10 minutes, and blocked with 5\% BSA for 1 hour at room temperature. The cells were labeled with the rabbit anti-tau (C-terminal) antibody (MilliporeSigma) or the mouse anti-phospho-Tau (Thr181) Clone AT270 antibody (Thermo Fisher Scientific) at room temperature at dilution of 1:1000 in $1 \%$ BSA for 1 hour and then labeled with Alexa Fluor488 goat anti-mouse IgG secondary antibody at a dilution of 1:500 for 30 minutes at room temperature. F-actin was stained with Alexa Fluor 594 phalloidin. The slides were examined using the Olympus BX61 DSU Fluorescence microscope. Digital fluorescence micrographs were recorded and analyzed with the ImageProPlus software.

\section{Results}

Tau protein is expressed in the smooth muscle

Tau protein expressed in neuronal cells is well known to play key roles in neurological disorders. However, whether the smooth muscle expresses tau protein is not known. We found that tau protein is expressed in the smooth muscle layer of cerebral vessels of brain tissues from human patients who died of ischemic stroke as visualized by immunohistochemistry (Fig. 1A). Similar results showing the expression of tau protein in brain vascular smooth muscle were obtained in 3 patient samples. Tau protein was also detected by Western blotting in cell lysates prepared from cultured human brain vascular smooth muscle cells (Fig. 1B). Two different sequences of siRNA reduced the intensity of the band, confirming that this $40 \mathrm{kDa}$ band is 
indeed tau protein expressed in smooth muscle cells (Fig. 1B). Similarly, tau protein expression was detected in human pulmonary artery smooth muscle cells (data not shown).

Tau protein is constitutively phosphorylated at threonine 181 in smooth muscle cells

We found that tau protein expressed in human brain vascular smooth muscle cells is constitutively phosphorylated at threonine 181 using Western blotting with a phospho-specific Tau antibody (Fig. 2). Similarly, the constitutively phosphorylated tau at threonine 181 was detected in human pulmonary artery smooth muscle cells of the lung vasculature as well as in human bronchial smooth muscle cells of the airways (Fig. 2).

\section{Cytoskeletal organization of tau and phosphorylated tau}

Immunofluorescence using the tau antibody shows dispersed total tau protein expression in the cytoplasm of human pulmonary artery smooth muscle cells (Fig. 3A). By contrast, tau protein phosphorylated at threonine 181 was found to be associated with the microtubule and is well organized in the cytoplasm as determined by immunofluorescence staining using the phospho-specific tau antibody (Fig. 3B).

\section{Effects of calyculin A}

Calyculin $\mathrm{A}$ is an inhibitor of protein phosphatase type 1 and $2 \mathrm{~A}$ that should promote protein phosphorylation (Lerea et al., 2007; Nishikawa et al., 1994). Our Western blotting experiments revealed that calyculin A produced multiple higher molecular weight species that can be detected by the phospho-tau (Thr181) antibody in human pulmonary artery smooth muscle cells (Fig. 4A). These higher molecular weight species largely occurred at about 80 and 
$160 \mathrm{kDa}$ and can be induced as early as $10 \mathrm{~min}$ of cell treatment with calyculin $\mathrm{A}$ and its formation continues to increase at $30 \mathrm{~min}$ (Fig. 4A). By contrast, subjecting cells to oxidative stress by the hydrogen peroxide treatment did not induce such higher molecular weight species (Fig. 4A). Molecular weights of 80 and $160 \mathrm{kDa}$ are consistent with the multimers of tau protein. These may be the product of phosphorylation-dependent tau aggregation.

Similarly, these high molecular weight species were also detected in airway smooth muscle cells treated with calyculin A. Fig. 4B shows that the treatment of human bronchial smooth muscle cells with calyculin A at $50 \mathrm{ng} / \mathrm{ml}$ caused for formation of higher molecular weight species of tau at $80,120,160$, and perhaps 200 or $240 \mathrm{kDa}$ in a time-dependent manner. The formation of high MW species occurred at as early as $10 \mathrm{~min}$ and continued to increase (Fig. 4B). Dose-dependence of calyculin A at 5, 20 and $50 \mathrm{ng} / \mathrm{ml}$ was also observed (Fig. 4B). We repeatedly and consistently observed the calyculin A-induced high molecular weight species formation as visualized using the phospho-tau (Thr181) antibody in smooth muscle cells in at least 10 experiments.

Immunofluorescence staining demonstrated that the treatment of human pulmonary artery smooth muscle cells with calyculin A disrupted the well organized cytoskeletal structure of tau phosphorylated at threonine 181 as seen in Fig. 3B and formed some protein aggregates as indicated by arrows (Fig. 5).

\section{Discussion}

Tau is a microtubule-associated protein that promotes the polymerization and assembly of microtubules and is considered to be one of the most important proteins in pathology of the central nervous system (Weingarten et al., 1975). It is located in the cellular compartment as well 
as in the interstitial fluid (Sotiropoulos et al., 2017). The abnormal accumulation of misprocessed tau is associated with various neurodegenerative diseases (Spillantini \& Goedert, 2013). It has recently been shown that that tau has multiple functions in addition to the axonal microtubule assembly. Tau binds to nucleic acid and modulates gene expression and RNA stability (Bou Samra et al., 2017). In pathological conditions, tau causes DNA and RNA damage, nuclear disorganization, RNA and ribosome instability, and changes in protein expression (Tsartsalis et al., 2018; Meier et al., 2016; Frost et al., 2014). Tau may also modulate and impair cell signaling, contributing to altered receptors activities and cell death (Hamdane et al., 2005; Burnouf et al., 2013; Ittner et al., 2010).

Our finding in the present study showing that tau protein is expressed in various smooth muscle tissue/cell types opens up the possibilities that this protein may play pathophysiological roles in vascular, airway and gastrointestinal systems by exhibiting various mechanisms that this protein can elicit as described above. Like in nervous system, smooth muscle tau can be phosphorylated. This study specifically examined tau phosphorylation at threonine 181 in the smooth muscle, however, enormous amounts of investigations are now warranted to understand the role of various phosphorylation sites within the tau protein molecule.

It is noteworthy that phosphorylated tau at threonine 181 specifically assemble in a well organized fashion in smooth muscle cells, while most of tau protein molecules seem to be not so organized. These results highlight the potential importance of the threonine 181 phosphorylation of tau in smooth muscle biology.

Our finding that calyculin A promotes aggregation of tau is also noteworthy in that the tau aggregation that is seen in neurodegenerative diseases can also occur in smooth muscle cells. Further, our results consistently producing the higher molecular weight species corresponding to 
multimers of tau protein by calyculin A treatment of cells suggest the usefulness of this protein phosphatase inhibitor for the research of tau aggregation in brain cells in order to combat Alzheimer's disease. It should be noted that Boban et al. (2019) reported that okadaic acid, another inhibitor of protein phosphatase type 1 and $2 \mathrm{~A}$, promoted the formation of high molecular weight tau species in SH-SY5Y cells. However, this tau species had a molecular weight of around $100 \mathrm{kDa}$ that is not consistent with the product of tau aggregation.

In summary, the present study showed, for the first time, that smooth muscle cells express tau protein and that smooth muscle tau is capable of being phosphorylated and aggregated. Future studies further understanding smooth muscle tau protein may shed a light on normal cell biology as well as developing therapeutic strategies to combat a wide variety of diseases that affect smooth muscle cells. 


\section{Acknowledgement}

This work was supported in part by NIH (R01HL072844, R21AI142649, R03AG059554, and R03AA026516) to YJS. The content is solely the responsibility of the authors and does not necessarily represent the official views of the NIH. 


\section{Reference}

1. Ballatore C, Lee VM, Trojanowski JQ. Tau-mediated neurodegeneration in Alzheimer's disease and related disorders. Nat Rev Neurosci. 2007; 8:663-672.

2. Binder LI, Frankfurter A, Rebhun LI. The distribution of tau in the mammalian central nervous system. J. Cell Biol 1985; 101:1371-1378.

3. Boban M, Babić Leko M, Miškić T, Hof PR, Šimić G. Human neuroblastoma SH-SY5Y cells treated with okadaic acid express phosphorylated high molecular weight tauimmunoreactive protein species. J Neurosci Methods. 2019; 319:60-68.

4. Bou Samra E, Buhagiar-Labarchede G, Machon C, Guitton J, Onclercq-Delic R, Green MR, Alibert O, Gazin C, Veaute X, Amor-Gueret M. A role for tau protein in maintaining ribosomal DNA stability and cytidine deaminase-deficient cell survival. Nat Commun. 2017; 8:693.

5. Braak H, Braak E. Neuropathological stageing of Alzheimer-related changes. Acta Neuropathol. 1991; 82:239-259.

6. Burnouf S, Martire A, Derisbourg M, Laurent C, Belarbi K, Leboucher A, Fernandez-Gomez FJ, Troquier L, Eddarkaoui S, Grosjean ME, Demeyer D, Muhr-Tailleux A, Buisson A, Sergeant N, Hamdane M, Humez S, Popoli P, Buee L, Blum D. NMDA receptor dysfunction contributes to impaired brain-derived neurotrophic factor-induced facilitation of hippocampal synaptic transmission in a tau transgenic model. Aging Cell. 2013; 12:11-23.

7. Chin SS, Goldman JE. Glial inclusions in CNS degenerative diseases. J Neuropathol Exp Neurol. 1996; 55:499-508.

8. Drubin DG, Kirschner MW. Tau protein function in living cells. J Cell Biol. 1986; 103:27392746. 
9. ElAli A, Theriault P, Prefontaine P, Rivest S. Mild chronic cerebral hypoperfusion induces neurovascular dysfunction, triggering peripheral beta-amyloid brain entry and aggregation. Acta Neuropathol Comm. 2013; 1:75.

10. Ervin JF, Pannell C, Szymanski M, Welsh-Bohmer K, Schmechel DE, Hulette CM. Vascular smooth muscle actin is reduced in Alzheimer disease brain: a quantitative analysis. J Neuropathol Exp Neurol. 2004; 63:735-741.

11. Evans LD, Wassmer T, Fraser G, Smith J, Perkinton M, Billinton A, Livesey FJ. Extracellular monomeric and aggregated tau efficiently enter human neurons through overlapping but distinct pathways. Cell Rep. 2018; 22:3612-3624.

12. Feany MB, Dickson DW. Neurodegenerative disorders with extensive tau pathology: a comparative study and review. Ann Neurol. 1996; 40:139-148.

13. Fernández-Nogales M, Cabrera JR, Santos-Galindo M, Hoozemans JJ, Ferrer I, Rozemuller AJ, Hernández F, Avila J, Lucas JJ. Altered levels and isoforms of tau and nuclear membrane invaginations in Huntington's disease. Front. Cell. Neurosci. 2019; 13:574.

14. Frost B, Hemberg M, Lewis J, Feany MB. Tau promotes neurodegeneration through global chromatin relaxation. Nat Neurosci. 2014; 7:357-366.

15. Grundke-Iqbal I, Iqbal K, Tung YC, Quinlan M, Wisniewski HM, Binder LI. Abnormal phosphorylation of the microtubule-associated protein tau (tau) in Alzheimer cytoskeletal pathology. Proc Natl Acad Sci U S A. 1986; 83:4913-4917.

16. Hamdane M, Bretteville A, Sambo AV, Schindowski K, Begard S, Delacourte A, Bertrand P, Buee L. p25/Cdk5-mediated retinoblastoma phosphorylation is an early event in neuronal cell death. J Cell Sci. 2005; 118:1291-1298. 
17. Hawkes CA, Gatherer M, Sharp MM, Dorr A, Yuen HM, Kalaria R, Weller RO, Carare RO. Regional differences in the morphological and functional effects of aging on cerebral basement membranes and perivascular drainage of amyloid-beta from the mouse brain. Aging Cell. 2013; 12:224-236.

18. Ingelson M, Vanmechelen E, Lannfelt L. Microtubule-associated protein tau in human fibroblasts with the Swedish Alzheimer mutation. Neurosci Lett. 1996; 220:9-12.

19. Ittner LM, Ke YD, Delerue F, Bi M, Gladbach A, van Eersel J, Wölfing H, Chieng BC, Christie MJ, Napier IA, Eckert A, Staufenbiel M, Hardeman E, Götz J. Dendritic function of tau mediates amyloid-beta toxicity in Alzheimer's disease mouse models. Cell. 2010; 142:387-397.

20. Johnson GVW, Hartigan JA. Tau protein in normal and Alzheimer's disease brain: an update. J Alzheimers Dis. 1999; 1:329-351.

21. Khurana V, Lu Y, Steinhilb ML, Oldham S, Shulman JM, Feany MB. TOR-mediated cellcycle activation causes neurodegeneration in a Drosophila tauopathy model. Curr Biol. 2006; $16: 230-241$.

22. Komori T. Tau-positive glial inclusions in progressive supranuclear palsy, corticobasal degeneration and Pick's disease. Brain Pathol. 1999; 9:663-679.

23. Lerea KM, Venjara AY, Olson SC, Kelly MR. Threonine phosphorylation of integrin beta3 in calyculin A-treated platelets is selectively sensitive to 5'-iodotubercidin. Biochim Biophys Acta. 2007; 1773:185-191.

24. Meyer EP, Ulmann-Schuler A, Staufenbiel M, Krucker T. Altered morphology and 3D architecture of brain vasculature in a mouse model for Alzheimer's disease. Proc Natl Acad Sci USA. 2008; 105:3587-3592. 
25. Meier S, Bell M, Lyons DN, Rodriguez-Rivera J, Ingram A, Fontaine SN, Mechas E, Chen J, Wolozin B, LeVine H, 3rd, Zhu H, Abisambra JF. Pathological tau promotes neuronal damage by impairing ribosomal function and decreasing protein synthesis. J Neurosci. 2016; 36:1001-1007.

26. Mudher A, Colin M, Dujardin S, Medina M, Dewachter I, Alavi Naini SM, Mandelkow EM, Mandelkow E, Buee L, Goedert M, Brion JP. What is the evidence that tau pathology spreads through prion-like propagation? Acta Neuropathol Commun. 2017; 5:99.

27. Mukrasch MD, von Bergen M, Biernat J, Fischer D, Griesinger C, Mandelkow E, Zweckstetter M. The "jaws" of the tau-microtubule interaction. J Biol Chem. 2017; 282:12230-12239.

28. Narasimhan S, Guo JL, Changolkar L, Stieber A, McBride JD, Silva LV, He Z, Zhang B, Gathagan RJ, Trojanowski JQ, Lee VMY. Pathological tau strains from human brains recapitulate the diversity of Tauopathies in nontransgenic mouse brain. J Neurosci. 2017; 37:11406-11423.

29. Nishikawa M, Toyoda H, Saito M, Morita K, Tawara I, Deguchi K, Kuno T, Shima H, Nagao M, Shirakawa S. Calyculin A and okadaic acid inhibit human platelet aggregation by blocking protein phosphatases types 1 and 2A. Cell Signal. 1994; 6:59-71.

30. Poorkaj P, Bird TD, Wijsman E, Nemens E, Garruto RM, Anderson L, Andreadis A, Wiederholt WC, Raskind M, Schellenberg GD. Tau is a candidate gene for chromosome 17 frontotemporal dementia. Ann Neurol. 1998; 43:815-825.

31. Qiang L, Sun X, Austin TO, Muralidharan H, Jean DC, Liu M, Yu W, Baas PW. Tau does not stabilize axonal microtubules but rather enables them to have long labile domains. Curr. Biol. 2018; 28:2181-2189. 
32. Rossi G, Dalprà L, Crosti F, Lissoni S, Sciacca FL, Catania M, Di Fede G, Mangieri M, Giaccone G, Croci D, Tagliavini F. A new function of microtubule-associated protein tau: involvement in chromosome stability. Cell Cycle. 2008; 7:1788-1794.

33. Rossi G, Conconi D, Panzeri E, Redaelli S, Piccoli E, Paoletta L, Dalprà L, Tagliavini F. Mutations in MAPT gene cause chromosome instability and introduce copy number variations widely in the genome. J Alzheimers Dis. 2013; 33:969-982.

34. Saha P, Sen N. Tauopathy: A common mechanism for neurodegeneration and brain aging. Mech Ageing Dev. 2019; 178:72-79.

35. Šimić G, Babić Leko M, Wray S, Harrington C, Delalle I, Jovanov-Milošević N, Bažadona D, de Silva R, Di Giovanni G, Wischik C, Hof PR. Tau protein hyperphosphorylation and aggregation in Alzheimer's disease and other tauopathies, and possible neuroprotective strategies. Biomolecules. 2016; 6:6.

36. Sotiropoulos I, Galas MC, Silva JM, Skoulakis E, Wegmann S, Maina MB, Blum D, Sayas CL, Mandelkow EM, Mandelkow E, Spillantini MG, Sousa N, Avila J, Medina M, Mudher A, Buee L. Atypical, non-standard functions of the microtubule associated tau protein. Acta Neuropathol Commun. 2017; 5:91.

37. Spillantini MG, Goedert M. Tau pathology and neurodegeneration. Lancet Neurol. 2013; 12:609-622.

38. Steinhilb ML, Dias-Santagata D, Mulkearns EE, Shulman JM, Biernat J, Mandelkow EM, Feany MB. S/P and T/P phosphorylation is critical for tau neurotoxicity in Drosophila. J Neurosci Res. 2007; 85:1271-1278.

39. Thurston VC, Zinkowski RP, Binder LI. Tau as a nucleolar protein in human nonneural cells in vitro and in vivo. Chromosoma. 1996; 105:20-30. 
40. Tsartsalis S, Xekardaki A, Hof PR, Kovari E, Bouras C. Early Alzheimer-type lesions in cognitively normal subjects. Neurobiol Aging. 2018; 62:34-44.

41. Vuono R, Winder-Rhodes S, de Silva R, Cisbani G, Drouin-Ouellet J. The role of tau in the pathological process and clinical expression of Huntington's disease. Brain. 2015; 138:19071918.

42. Wang Y, Mandelkow E. Tau in physiology and pathology. Nat. Rev. Neurosci. 2016; 17:2235.

43. Weingarten MD, Lockwood AH, Hwo SY, Kirschner MW. A protein factor essential for microtubule assembly. Proc. Natl. Acad. Sci. USA. 1975; 72:1858-1862. 
Fig. 1
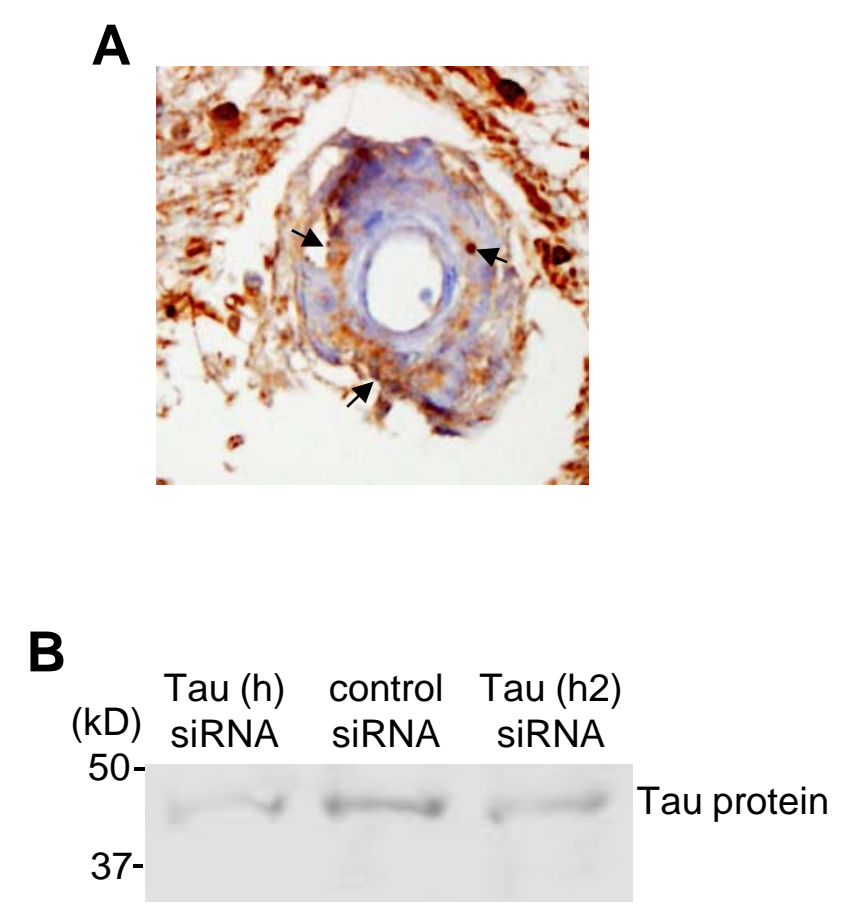

Fig. 1: Tau protein is expressed in smooth muscle cells. (A) Immunohistochemistry shows that tau protein is expressed in the brain vascular smooth muscle tissues from patients with systemic hypertension died of ischemic stroke. (B) Cultured human brain vascular smooth muscle cells transfected with control, Tau (h) or Tau (h2) siRNA. 48 hours later, cell lysates were prepared. Western blotting with the Tau antibody. 
Fig. 2

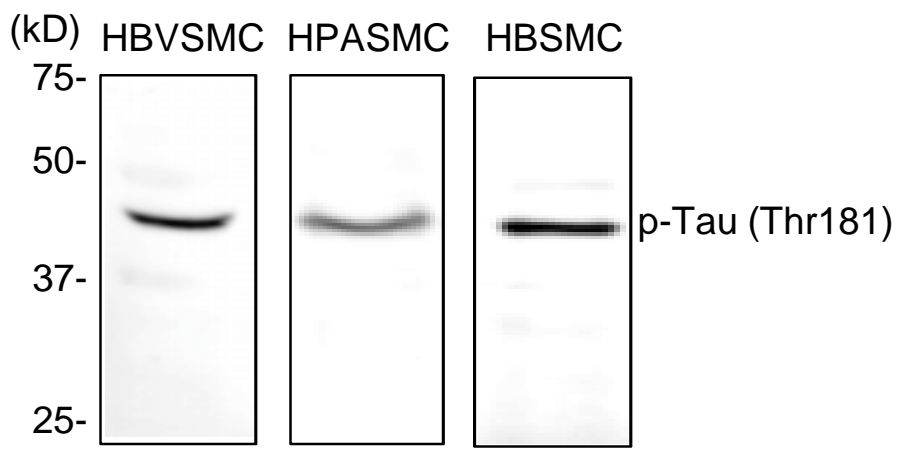

Fig. 2: Threonine 181 of tau protein is constitutively phosphorylated in various smooth muscle cell types. Cell lysates prepared from cultured human brain vascular smooth muscle cells (HBVSMC), human pulmonary artery smooth muscle cells (HPASMC), and human bronchial smooth muscle cells (HBSMC) were subjected to Western blotting using the antibody against phosphorylated tau at Threonine 181. 
Fig. 3
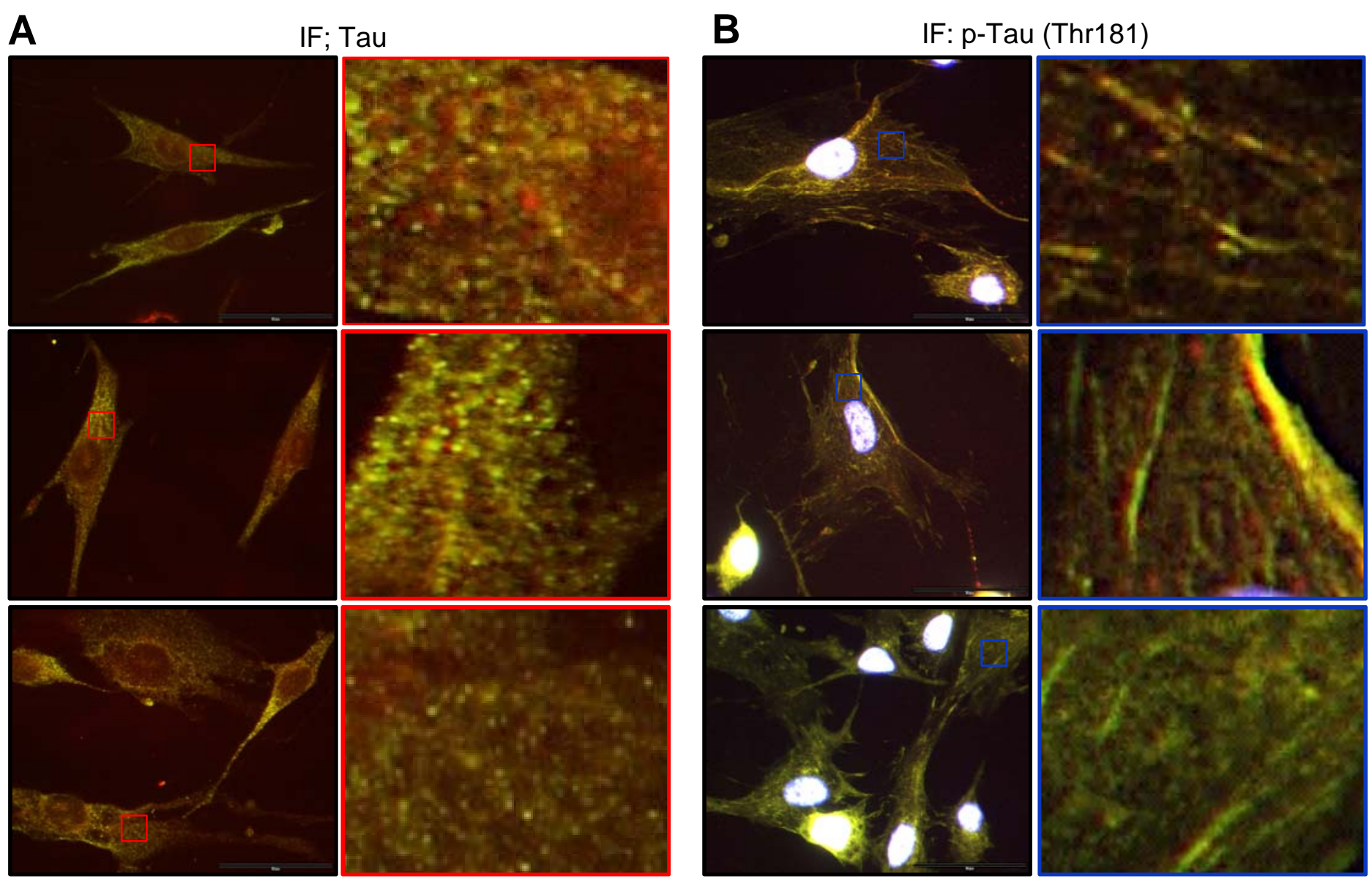

Fig. 3: Tau protein that is phosphorylated at threonine 181 is highly organized in smooth muscle cells. Human pulmonary artery smooth muscle cells were subjected to immunofluorescence (IF) analysis using (A) the tau protein antibody and (B) phospho-specific tau (Thr 181) antibody ( $\mathrm{p}$-Tau). Areas indicated with squares are shown enlarged on the right side of each image. These images show a well assembled network of phosphorylated tau localized along the microtubules, while tau protein molecules that are not phosphorylated at threonine 181 are not well organized. 

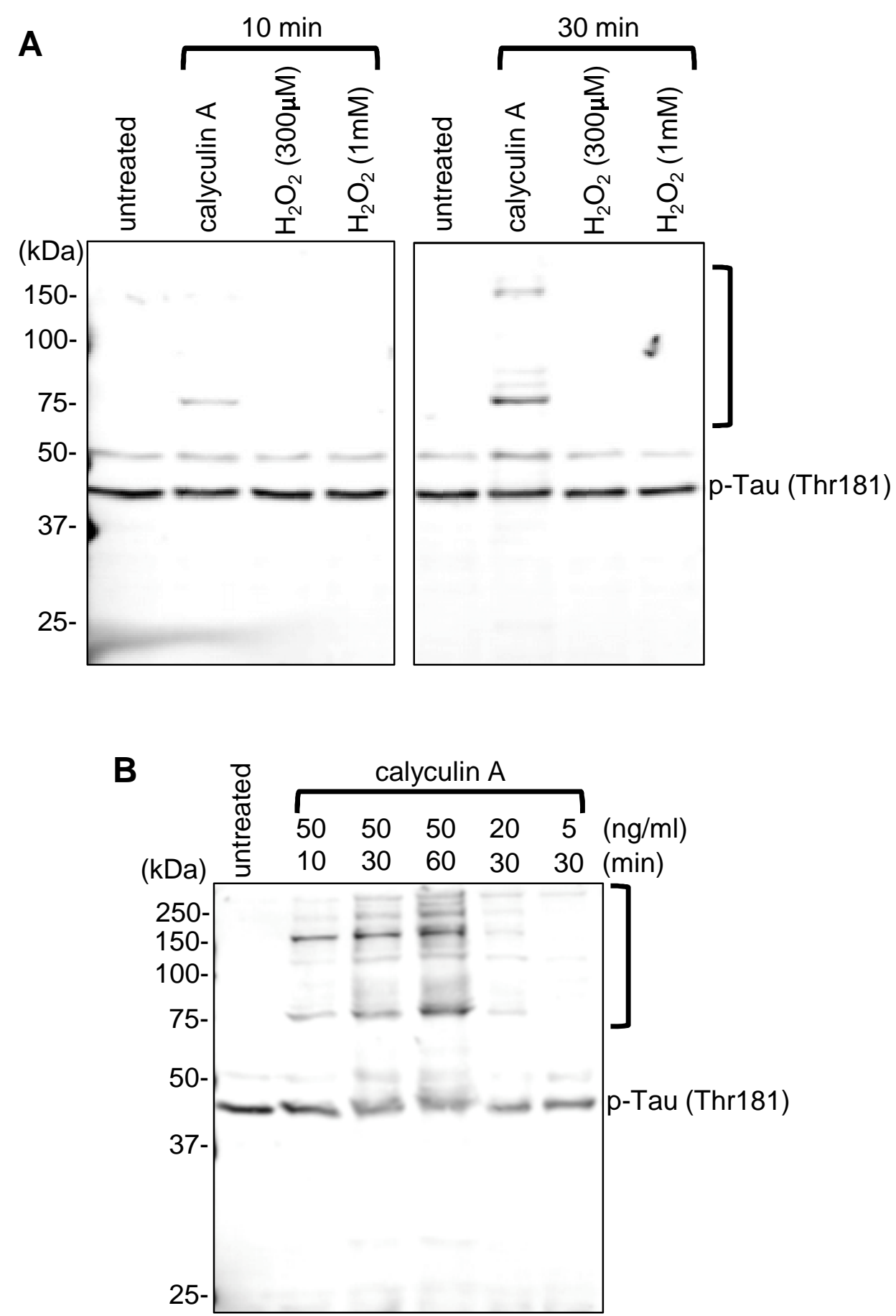

Fig. 4: Calyculin A forms high molecular phosphorylated tau species. (A) Human pulmonary artery smooth muscle cells were treated with calyculin $A(50 \mathrm{ng} / \mathrm{ml})$ or hydrogen peroxide $\left(\mathrm{H}_{2} \mathrm{O}_{2}\right)$ for durations indicated. (B) Human bronchial smooth muscle cells were treated with various doses of calyculin $A$ for durations indicated. Cell lysates were subjected to Western blotting with the antibody against phosphorylated tau protein at threonine 181, p-Tau (Thr181). 


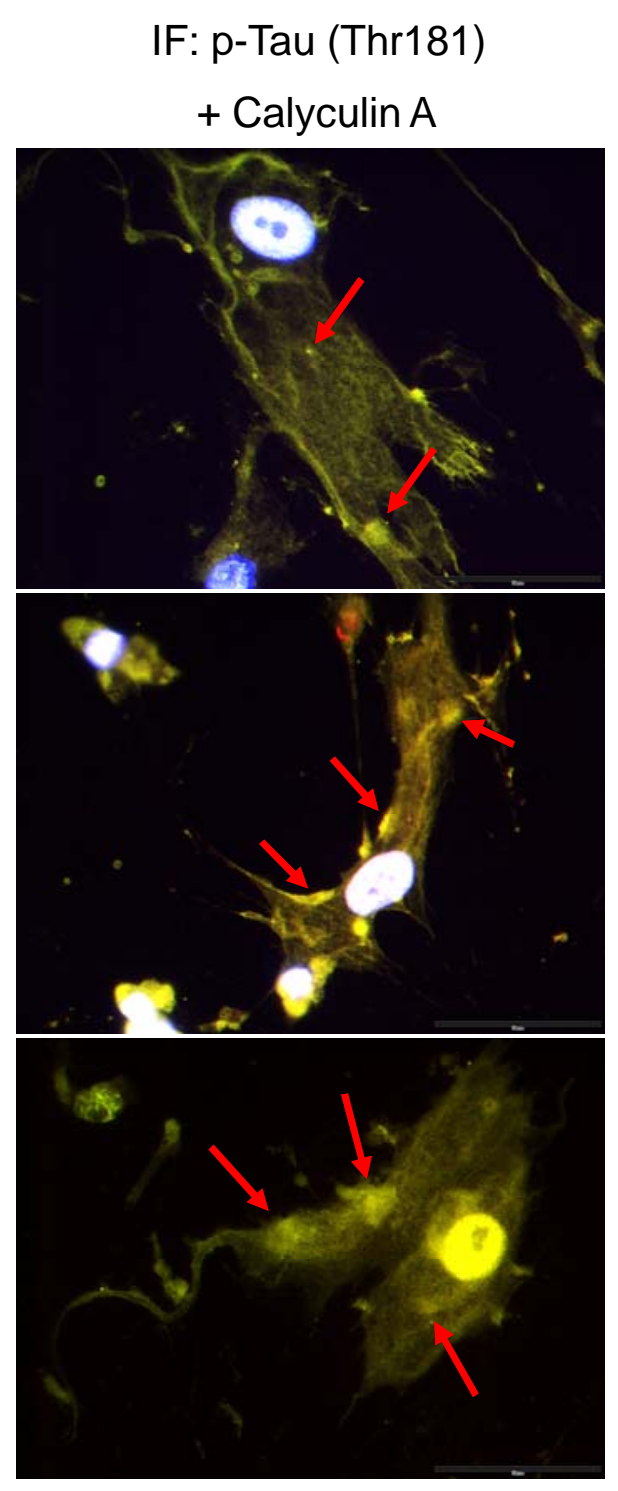

Fig. 5: Calyculin A disturbs phosphorylated tau organization. Human pulmonary artery smooth muscle cells were treated with calyculin A $(50 \mathrm{ng} / \mathrm{ml})$ for $30 \mathrm{~min}$ and subjected to immunofluorescence (IF) analysis using the antibody against phosphorylated tau protein at threonine 181, p-Tau (Thr181). The representative images show the absence of well assembled microtubules as well as dispersed phosphorylated tau. The aggregation of phosphorylated tau is also visible as indicated with arrows. 